Revista Voluntas: Estudos sobre Schopenhauer - Vol. 3, Números 1 e 2 - $1^{\text {o e }} 2^{\text {o }}$ semestres de 2012 - ISSN: 2179-3786 - pp. 20-29.

\title{
Schopenhauer e os Cínicos: elementos do cinismo na eudemonologia de Schopenhauer
}

\author{
Schopenhauer and the Cynics: elements of cynicism in schopenhauerian \\ eudemonology
}

\author{
Leandro Chevitarese \\ Doutor em Filosofia pela PUC-Rio e Professor Adjunto de Filosofia da UFRRJ \\ E-mail: leandrochevitarese@yahoo.com.br
}

\begin{abstract}
Resumo: O presente artigo pretende investigar as raízes cínicas que se fazem presentes na eudemonologia schopenhaueriana, tendo em vista a possibilidade de melhor compreender tal orientação para uma "vida menos infeliz". Partindo da leitura que Schopenhauer desenvolve acerca da prática de vida dos cínicos, compreendida como matriz da elaboração teórica do estoicismo, pretende-se considerar quais elementos estariam significativamente presentes em sua proposta de uma "ética empírica" para enfrentar o "mal de viver".
\end{abstract}

Palavras-chave: Eudemonologia; Cínicos; Ética Empírica.

Abstract: This article investigates the cynical roots that are present in Schopenhauer's eudemonology, in order to better understand the possibility of this orientation leading to a "less miserable life." Based on the reading that Schopenhauer develops about the practice of life of the Cynics, understood as a matrix of theoretical elaboration of Stoicism, we intend to consider what elements would be significantly present in his proposal for an "empirical ethics" to confront the "evil of life."

Keywords: Eudemonology; Cynics; Empirical Ethics.

A leitura de Schopenhauer acerca do estoicismo ${ }^{1}$ é fundamental para elaboração de sua eudemonologia, na qual desenvolve o conceito de Razão Prática aplicado à possibilidade de conquista da Sabedoria de Vida. Em tal proposta, o filósofo procura responder a questão: tendo em vista que fundamentalmente a "vida é sofrimento", qual a melhor forma de conceber uma orientação para uma “vida menos infeliz"? Ou ainda, em outras palavras: como viver diante da tragédia da existência?

Entretanto, apesar da significativa influência do estoicismo em tal perspectiva eudemonológica, existem razoáveis dissonâncias entre este sistema teórico e a filosofia de Schopenhuaer, se tomada em conjunto. Resumidamente, as principais dificuldades observadas pelo filósofo no estoicismo referem-se a três elementos: (1) há uma incontornável contradição em “querer viver sem sofrer”; (2) há uma inaceitável recomendação de suicídio para tal vida feliz; (3) em sentido estrito, há uma impossível realização da autodeterminação da vontade por meio da razão. Tais objeções podem encontrar

\footnotetext{
${ }^{1} \mathrm{O}$ presente artigo é uma continuação da pesquisa que venho desenvolvendo, cuja primeira parte foi apresentada no IV Colóquio Internacional Schopenhauer, realizado em 2011, em Florianópolis, sob o título: "Schopenhauer e o Estoicismo". O Artigo foi publicado pela Revista Etic@, UFSC, vol.11, n.2 (2012). Disponível em http://periodicos.ufsc.br/index.php/ethic/. Deste modo, alguns dos argumentos ali apresentados serão retomados para o desenvolvimento deste texto.
} 
"resposta" na própria obra de Schopenhauer, respectivamente: (1) a eudemonologia é um eufemismo, trata-se de promover uma "vida menos infeliz"; (2) embora não haja uma reprovação moral ao suicídio $^{2}$ per si, não há por que tê-lo como recomendação ética; (3) a eudemonologia é uma "ética do como se", ou seja, façamos "como se" a vida valesse a pena e "como se" a razão pudesse determinar a vontade - pois o intelecto certamente pode sugestioná-la, criando condições para o exercício da "liberdade de ser o que se é"3.

Diante deste cenário, e partindo da afirmação de Schopenhauer de que "o estoicismo adveio do cinismo, no sentido de que converteu a prática em teoria" ${ }^{4}$, o presente artigo pretende investigar as raízes cínicas que se fazem presentes na eudemonologia schopenhaueriana. Não se pretende aqui, todavia, desenvolver uma análise de conjunto de uma possível filosofia cínica em contraste com a metafísica imanente de Schopenhauer, inclusive, ao que tudo indica, sustentam-se as mesmas dissonâncias observadas em relação ao estoicismo. Na verdade, tem-se como objetivo mapear os elementos cínicos presentes na proposta schopenhaueriana da Sabedoria de Vida, a partir da leitura que o filósofo desenvolve acerca da prática de vida dos cínicos ${ }^{5}$, tendo em vista a possibilidade de melhor compreender esta liberdade que nos resta para enfrentar o "mal de viver".

O filósofo refere-se aos cínicos ou ao cinismo em pontos muito específicos de sua obra ${ }^{6}$, a saber: no Suplemento XVI, dedicado ao parágrafo 16 de $O$ Mundo como Vontade e como

\footnotetext{
${ }^{2}$ É famosa a recusa de Schopenhauer ao suicídio como alternativa para a Negação da Vontade tal como formulado no parágrafo 69 de sua principal obra. Do mesmo modo, é evidente sua reprovação como perspectiva eudemonológica. Apesar disso, não há uma reprovação moral propriamente dita a tal ato. Para uma consideração complementar ao tema, ver: Parerga e Paralipomena, vol.2, "Sobre o Suicídio", parágrafos 157 a 160 (cf. a tradução de Flamarion Ramos em: SCHOPENHAUER: Sobre a Ética. São Paulo: Hedra, 2012).

${ }^{3}$ Este é o tema de minha tese de doutorado: CHEVITARESE, L. A Ética em Schopenhauer: que "liberdade nos resta" para a prática de vida? Departamento de Filosofia. PUC-Rio, 2005.

${ }^{4}$ SCHOPENHAUER, MVR II, XVI, p. 845. (As páginas para MVR II seguem a tradução francesa).

${ }^{5}$ Conforme bem observa PINHEIRO, Ascese cinica e a oposição Nómos e Phýsis, p.1: "Uma das questões importantes sobre o cinismo trata sobre sua unidade. Haveria realmente, como parece supor Diógenes Laércio, uma única escola cínica, que começaria com Antístenes, formando um processo de mestre e aprendiz até Menipo e Menedemo? Muitos comentadores, começando com o livro de referência de DUDLEY, D. R. A history of cynicism. Methuen: London, 1937, criticaram esta postura unitária do cinismo que encontramos nas Vidas e Doutrinas dos Filósofos Ilustres de Diógenes Laércio, chegando a defender que de Antístenes nem se poderia afirmar que seria um cínico. A argumentação básica atribui a criação do cinismo unitário aos estóicos que gostariam de ver sua escola conectada a figura de Sócrates, ao colocar Zenão, o estóico, como aluno de Crates, formando a linha sucessória Zenão, Crates, Diógenes, Antístenes, Sócrates". De fato, como Schopenhauer considera o Estoicismo uma "elaboração teórica da prática cínica" e sendo Diôgenes Laêrtius sua principal fonte do Cinismo, ao que tudo indica, o filósofo partilhava desta concepção de um "cinismo unitário".

${ }^{6}$ Pode-se destacar inclusive que as palavras "Kynismus" e "Kyniker" aparecem somente nestas indicações, em toda a obra publicada de Schopenhauer. Sobre o uso dos termos, como bem observa NIEHUES-PRÖBSTING, A recepção moderna do cinismo. Diógenes e o Iluminismo, p. 362: "Em contraste com outros idiomas europeus, a forma Cynismos, que até esse ponto havia sido deixada uniforme, foi deixada de lado na Alemanha do século XIX e substituída pela distinção entre Kynismus - que designa exclusivamente a filosofia de Antístenes e Diógenes e de seus sucessores clássicos - e Zynismus como o nome para uma atitude que não reconhece nada como sagrado e que insulta valores, sentimentos e o decoro provocativamente, com sarcasmo mordaz, ou mesmo por meio de indiferença deliberada. Sobre o surgimento do conceito moderno de cinismo (Zynismus) a partir da recepção do cinismo (Kynismos) cf. NIEHUES-PRÖBSTING: Der Kynismus des Diogenes uns der Begriff des Zynismus, Frankfurt, 1988".
} 
Representação, em Fragmentos para História da Filosofia, Cap. 6, "Os Estóicos", bem com em Aforismos para Sabedoria de Vida, Capítulo V - ambos incluídos em Parerga e Paralipomena, vol.1.

Como trataremos da articulação entre o cinismo e a proposta eudemonológica de Schopenhauer, vejamos em primeiro lugar a formulação em Aforismos para Sabedoria de Vida ${ }^{7}$. O filósofo menciona o cinismo ao tratar da Máxima Geral para Sabedoria de Vida, retirada da obra de Aristóteles: "O prudente aspira não ao prazer, mas a ausência de dor". Para Schopenhauer, somente as dores são sentidas "positivamente", consequência de algum entrave ou obstáculo para a vontade, deste modo tem-se que apenas a ausência de dor é um critério para aquilo que pudermos considerar como "felicidade". Como o sofrimento faz-se presente tanto pela não realização de nossos anseios pessoais, como pelo desejo que não encontra objeto, ou seja, pelo tédio, temos então a bela formulação schopenhaueriana: "Se a um estado sem dor ainda couber a ausência de tédio, então a felicidade terrena foi essência alcançada; o resto é quimera"8. É na sequência desta análise que o filósofo refere-se ao cinismo:

A partir disso, podemos até deduzir a ideia fundamental do cinismo, tal como expus na minha obra principal, v. II, cap.16. Pois o que levava os cínicos à rejeição dos prazeres era tão-só o pensamento de que as dores estavam mais ou menos ligadas a eles, e desviar-se delas parecia-lhes muito mais importante do que alcançar os prazeres. Os cínicos estavam profundamente imbuídos do conhecimento da negatividade do prazer e da positividade da dor; consequentemente, faziam de tudo para evitar os males, julgando necessária a completa e intencional rejeição dos prazeres, pois viam nestes apenas armadilhas que nos entregam à dor? .

Tal como em Fragmentos para História da Filosofia, Schopenhauer, ao tratar do estoicismo, remete o leitor a MVR: "Para esta questão remeto à minha obra principal, volume I, parágrafo 16, e volume II, capítulo 16 - onde, e de certo pela primeira vez, o verdadeiro espírito do cinismo e da Stoa é exposto em profundidade" ${ }^{10}$. O referido parágrafo 16 de MVR Schopenhauer dedica-se a analisar a "faculdade da razão na medida em que conduz a ação das pessoas, portanto, podendo nesse aspecto ser denominada prática" ${ }^{11}$. É neste contexto que apresenta sua análise do estoicismo:

O desenvolvimento perfeito da Razão Prática, no verdadeiro e autêntico sentido do termo, o ápice do que o homem pode chegar mediante o simples uso da Razão, com o que a sua diferença do animal se mostra na maneira mais nítida, foi exposto, enquanto ideal, na Sabedoria Estóica. Pois a ética não é originária e essencialmente uma

\footnotetext{
${ }^{7}$ SCHOPENHAUER, Aforismos para Sabedoria de Vida. Trad. Jair Barboza. São Paulo: Martins Fontes, 2002 (Doravante ASV).

${ }^{8}$ SCHOPENHAUER, ASV, p.142.

${ }^{9}$ SCHOPENHAUER, ASV, p. 144.

${ }^{10}$ SCHOPENHAUER, Fragmentos para a História da Filosofia, p. 144.

${ }^{11}$ SCHOPENHAUER, MVR I, § 16, pp. 138-139 (As páginas para MVR I seguem a tradução brasileira).
} 
doutrina da virtude, mas mera instrução para uma vida racional, cujo fim e objetivo é a felicidade mediante a tranqüilidade de ânimo ${ }^{12}$.

Mas é apenas no Suplemento (XVI) ao parágrafo 16 de MVR, intitulado "Sobre o uso prático da razão e sobre o estoicismo", que filósofo procura destacar que muitos elementos presentes na filosofia estóica foram absorvidos do cinismo, que já buscava "uma existência isenta de dores"13. O estoicismo seria um desenvolvimento e elaboração teórica da prática cínica. Para o filósofo, a ideia fundamental do cinismo, tal como presente em Diôgenes, afirma a necessidade de escolher a vida em sua forma mais simples e nua, ainda que repleta das misérias e sofrimentos que a natureza lhe impõe. Todavia, tais dificuldades seriam ainda bem menores do que todas aquelas proporcionadas pela ambição e desejo acerca dos "bens" ofertados pela vida social. Caberia, portanto, recusar os prazeres e os benefícios da sociedade, fixando-se apenas naquilo que não se pode perder, ou seja, em si mesmo. Trata-se do esforço de viver em conformidade com a natureza, dependendo apenas daquilo que lhe é próprio $^{14}$. Os cínicos teriam deixado como legado o princípio de que toda dinâmica implícita à tentativa de realização dos desejos, incluindo o medo da perda daquilo que, eventualmente, se conseguiu obter, é muito mais dolorosa do que a privação de todo e qualquer objeto do desejo ${ }^{15}$.

Para Schopenhauer, a seguinte proposição pode ser compreendida como um resumo da doutrina cínica: "Diôgenes proclamava freqüentemente que os deuses haviam concedido aos homens meios fáceis de vida, porém os homens perderam de vista esse beneficio, pois necessitam de bolos de mel, de ungüentos e de coisas semelhantes"16. Esta é uma das duas únicas citações de Schopenhauer referentes a Diôgenes, o Cínico. Nela pode-se observar sua interpretação de que o cinismo compreendeu a "negatividade" do prazer, ou seja, a perspectiva de que uma "vida menos infeliz" só se pode conquistar por meio da diminuição das expectativas e desejos, jamais pela ênfase em sua realização. A dinâmica do desejo é insaciável e a vida é sofrimento. De fato, em sua análise sobre a recepção moderna do cinismo, Niehues-Pröbsting evidencia que "pelas lentes de Schopenhauer, a essência do cinismo é vista na tensão entre pessimismo e eudemonismo. (...) O cínico conhece o sofrimento da vida; nisso ele é

\footnotetext{
${ }^{12}$ Ibidem, p.142.

${ }^{13}$ SCHOPENHAUER, MVR II, XVI, p. 840, meus grifos.

${ }^{14}$ Pode-se observar aqui a importante temática da oposição entre nómos e phýsis na prática dos cínicos. Para uma análise cuidadosa de tal questão ver: PINHEIRO, Ascese cínica e a oposição entre Nómos e Phýsis; e GOULET-CAZÉ, M.O. L 'Ascese Cynique. Um Commentaire de Diogène Laerce VI 70-71.

${ }^{15}$ Cf. SCHOPENHAUER, MVR II, XVI, p. 842.

${ }^{16}$ Diôgenes Laêrtius, VI, 2, apud SCHOPENHAUER, MVR II, XVI, p.843. Schopenhauer cita um trecho do parágrafo 44, do famoso livro de Diôgenes Laêrtius. Eis o parágrafo na íntegra (trechos citados em negrito): “Em outra ocasião Perdicas ameaçou-o de morte se não fosse à sua presença. Diôgenes respondeu: 'Nada há de extraordionário nessa ameaça, pois até um escaravelho ou uma tarântula poderia matar-me'. Em vez disso ele acharia natural que a ameaça fosse no sentido de que Perdicas poderia viver perfeitamente feliz sem a sua companhia. Diôgenes proclamava freqüentemente que os deuses haviam concedido aos homens meios fáceis de vida, porém os homens perderam de vista esse beneficio, pois necessitam de bolos de mel, de ungüentos e de coisas semelhantes. Pensando assim, a alguém que se deixava calçar por um servo, Diôgenes disse: 'Ainda não és feliz se este servo não te abana também o nariz; atingirás a felicidade completa quando tiveres perdido o uso das mãos"” (LAÊRTIUS, D. Vidas e Doutrinas dos Filósofos Ilustres, p.159).
} 
um pessimista. O pessimismo cínico, porém, não leva a uma negação da vida" ${ }^{17}$. E talvez esta seja a principal característica da proposta de Aforismos para a sabedoria de vida: articular uma visão de mundo pessimista com uma prática de vida eudemonológica - precisamente o que Schopenhauer interpreta na prática de vida cínica. Segundo o filósofo, o principal objetivo da prática cínica é aproximar-se de uma vida que evite ao máximo a dor, ou seja, de uma vida tão feliz quanto nos é possível $^{18}$.

A segunda citação que Schopenhauer faz no Livro VI de Diôgenes Laêrtius, Sobre os Cínicos, parece-me também particularmente importante:

Com efeito, nada na vida se pode obter sem exercício, e este é capaz de sobrepor-se a tudo. Eliminados então os esforços inúteis, o homem que escolhe somente os esforços em conformidade com a natureza vive feliz. A falta de discernimento para perceber os esforços necessários é a causa da infelicidade humana (...) e afirmava que sua maneira de viver era a de Hércules, que preferia a liberdade a tudo mais ${ }^{19}$.

A temática do exercício é fundamental para a compreensão da proposta eudemonológica de Schopenhauer: "agir por princípios abstratos é difícil e sucede apenas após muito exercício, e mesmo assim nem sempre: muitas vezes esses princípios também não são suficientes" ${ }^{20}$. As orientações para a Sabedoria de Vida são indissociáveis de uma áskesis, ou seja, de uma prática constante de exercícios sobre si mesmo, cujos esforços precisam direcionar-se para a construção de um modo de vida em consonância com sua própria natureza. Mas cabe salientar: estamos aqui bem distantes de um ascetismo cristão ou hindu. Para Schopenhauer, tanto o cinismo como o estoicismo não apresentam tendências metafísicas transcendentes, permanecendo na mais absoluta imanência: seu alvo é apenas a ataraxia, o estado da inabalável felicidade do sábio ${ }^{21}$. O tipo de ascese que podemos encontrar nestas práticas constitui-se como um retorno a si mesmo, uma conversão a si, jamais uma "renúncia" ou abandono da individualidade em prol de algum princípio maior de natureza transcendente. Em função disso, o filósofo ressalta que a diferença entre a prática dos cínicos e o ascetismo dos sanyasis

\footnotetext{
${ }^{17}$ NIEHUES-PRÖBSTING, A recepção moderna do cinismo. Diógenes e o Iluminismo, p.388, meus grifos.

${ }^{18}$ Cf. SCHOPENHAUER, MVR II, XVI, p. 849.

${ }^{19}$ LAÊRTIUS, D, VI, 2, apud SCHOPENHAUER, MVR II, XVI, p. 843. Schopenhauer cita agora um trecho do parágrafo 71. Eis o parágrafo na íntegra (os trechos citados em negrito): “Com efeito, nada na vida se pode obter sem exercício, e este é capaz de sobrepor-se a tudo. Eliminados então os esforços inúteis, o homem que escolhe somente os esforços em conformidade com a natureza vive feliz. A falta de discernimento (ou loucura) para perceber os esforços necessários é a causa da infelicidade humana. O próprio desprezo do prazer para quem está habituado a ele é sumamente agradável. E da mesma forma que as pessoas habituadas a viver em meio aos prazeres passam relutanemente a um modo de viver oposto, aqueles que se exercitam de maneira contrária desprezam com maior naturalidade os próprios prazeres. Eram estes os seus preceitos, e por eles Diôgenes moldou sua vida. De fato, ele adulterou moeda corrente porque atribuía importância menor às prescrições das leis que às da natureza, e afirmava que sua maneira de viver era a de Hércules, que preferia a liberdade a tudo mais" (LAÊRTIUS, D. Vidas e Doutrinas dos Filósofos Ilustres, p.170).

${ }^{20}$ SCHOPENHAUER, ASV, p. 236, meu grifo.

${ }^{21}$ Cf. SCHOPENHAUER, MVR II, XVI, p. 849.
} 
manifesta-se de modo mais notável em relação à humildade - completamente estranha ao cinismo ${ }^{22}$. Pode-se ainda acrescentar que não haveria nesta áskesis cínica ${ }^{23}$ qualquer relação com a experiência da compaixão, ainda menos com a Negação da Vontade, ao contrário, trata-se de uma afirmação consciente da vontade de vida numa conjugação entre pessimismo e eudemonismo. Parece-me fundamental destacar que tal proposta depende de um "voltar-se sobre si mesmo", o que pode ser uma importante perspectiva de compreensão de toda a proposta eudemonológica de Schopenhauer. A experiência da "liberdade que nos resta" depende de uma conversão a si mesmo. Tal ênfase pode ser bem observada também nas citações de Zenão, evidenciadas pelo filósofo, em sua análise do estoicismo: “Viver em consonância, isto é, segundo um único princípio e em concórdia consigo mesmo' / 'A virtude consiste na concordância do espírito consigo mesmo durante toda a vida"'24.

Este conjunto de exercícios corresponde ao esforço para construção do que Schopenhauer denomina de caráter adquirido ${ }^{25}$. Trata-se de investir no aprendizado que é possível em nosso curso de vida, visando "empregar a personalidade, tal qual nos foi dada, para os maiores proveitos possíveis, (...) consequentemente, escolher o estado, a ocupação, a maneira de vida que lhe forem adequados ${ }^{26}$. "O perfeito homem do mundo" - o ideal da prudência para Schopenhauer - "seria aquele que jamais hesitasse por indecisão e nunca agisse por precipitação"27. Todavia, como observamos no início do presente artigo, diferentemente do estoicismo, Schopenhauer não alimenta a ilusão de que sejamos “perfeitamente” prudentes. O caráter adquirido é um artifício, uma estratégia, um exercício. E artifícios podem sempre falhar. De qualquer modo:

(...) não se deve, por conta disso, perder a coragem e pensar que é impossível dirigir nossa conduta na vida mundana em conformidade por regras e máximas abstratas, e que, portanto, seria melhor não nos controlarmos. Nesse caso, dá-se o mesmo que em todas as prescrições e instruções teóricas para o uso prático: compreender a regra é o

\footnotetext{
${ }^{22}$ Cf. SCHOPENHAUER, MVR II, XVI, p. 845.

${ }^{23}$ A outra passagem relatada por Diôgenes Laêrtius (Livro VI, Cap. 2, par. 70) que trata da áskesis cínica é a seguinte: "Diôgenes dizia que há dois tipos de exercício: o espiritual e o físico. Na prática constante do exercício físico formam-se percepções que tomam mais expedita a prática da excelência. O exercício físico e o espiritual se integram e se completam. As condições físicas satisfatórias e o vigor são elementos fundamentais para a saúde da alma e do corpo. Aduzia provas para demonstrar que o exercício físico contribui para a conquista da excelência. Observava que tanto os artesãos humildes como os grandes artistas adquiriam habilidade notável graças ao exercício constante de sua arte, e que os flautistas e os atletas deviam sua superioridade a uma dedicação assídua e fatigante. E se estes transferissem seus esforços para o aprimoramento da alma, tais esforços não seriam inúteis nem destituídos de objetivo" (LAÊRTIUS, 2008, p. 170). Estes dois parágrafos que tratam mais propriamente da áskesis cínica são objeto do livro de GOULET-CAZÉ. L'Ascese Cynique. Um commentaire de Dogène Laerce VI 70-71.

${ }^{24}$ SCHOPENHAUER, MVR I, § 16, p.145.

${ }^{25} \mathrm{O}$ caráter adquirido (erworbenen Charakter) é "este que se forma pela prática do mundo; é deste que se fala quando se louva um homem por ter caráter, ou quando se o censura por não ter" (MVR $\S 55$, p. 318). Tal concepção de "caráter” é fundamental para eudemonologia de Schopenhauer, constituindo-se no resultado possível dos esforços para construção de uma Sabedoria de Vida.

${ }^{26}$ SCHOPENHAUER, ASV, p. 11.

${ }^{27}$ Idem, p.m 244.
} 
primeiro passo, o segundo é aprender a aplicá-la. A compreensão é adquirida de uma só vez pela razão, o aprendizado é absorvido aos poucos pelo exercício ${ }^{28}$.

O aprendizado depende de esforço e exercício, mostrando-se como uma tarefa árdua, um desafio. E não se deve negligenciar a ênfase schopenhaueriana para a virtude da coragem neste processo, pois “depois da inteligência, a coragem é uma qualidade bastante essencial para nossa felicidade, (...) [e] mediante firme propósito e exercício, podemos incrementar o que já possuímos" ${ }^{29}$. Neste horizonte interpretativo, vale destacar que há uma significativa articulação entre "coragem" e "paciência" em Schopenhauer. Trata-se de conceber tal qualidade como um sereno e persistente enfrentamento da adversidade, como se pode bem observar neste trecho de Parerga e Paralipomena (vol.2, § 111):

A coragem pode ser compreendida pelo fato de que se enfrenta uma ameaça no momento presente para prevenir maiores males no futuro, enquanto a covardia faz o contrário. A primeira atitude é o caráter da paciência, que consiste na clara consciência que existem males ainda piores do que do presente quer poderiam ser precipitados pela fuga ou repulsão violenta. Por conseguinte, a coragem seria uma espécie de paciência, e como é justamente ela que nos torna capazes de todo o tipo de privações e autossuperações é por meio dela que a coragem é ao menos aparentada à virtude ${ }^{30}$.

A autossuperação no trato consigo mesmo, diante das intempéries e vicissitudes da vida, constitui-se como elemento intrínseco à perspectiva do "bem-viver". Neste contexto, podemos identificar uma interessante raiz de tal entendimento na prática cínica acerca da "coragem"31, como evidencia a famosa narrativa sobre o encontro entre Diôgenes e Alexandre, o Grande:

Diôgenes afirmava que à sorte podia opor a coragem, às convenções a natureza, à paixão a razão. Enquanto em certa ocasião o filósofo tomava sol no Cranêion, Alexandre, o Grande, chegou, pôs-se à sua frente e falou: "Pede-me o que quiseres!" Diôgenes respondeu: "Deixa-me o meu sol!"

Este relato sinaliza o contraste entre a autossuficiência, o autodomínio (autarkeia) de Diôgenes, que se satisfaz com o que a natureza lhe concede, e a dinâmica de vida própria ao homem comum -

\footnotetext{
${ }^{28}$ SCHOPENHAUER, ASV, pp. 215-216, grifos meus.

${ }^{29}$ Idem, p. 244, grifo meu.

${ }^{30}$ SCHOPENHAUER, P/P, vol.2, § 111, pp. 43-44 (As páginas seguem a tradução brasileira deste trecho de P/P).

${ }^{31}$ Há uma íntima relação entre o filosofar e a coragem na prática cínica, o que pode ser bem observado na seguinte passagem: "Perguntaram-lhe o que ganhava com a filosofia, e a resposta foi: "no mínimo, estar preparado para enfrentar todas as vicissitudes da sorte"". Tal enfrentamento do curso da vida relaciona-se diretamente com o esforço pelo bem-viver, o cuidado de si, conforme o trecho: "A alguém que lhe declarou: 'Não tenho inclinação para a filosofia', Diôgenes disse: 'Por que vives, se não cuidas de viver bem?'”. LAÊRTIUS, Vidas e doutrinas dos filósofos ilustres, p.168.

${ }^{32}$ LAÊRTIUS, D. Vidas e doutrinas dos filósofos ilustres, pp. 160-161, grifos meus.
} 
ainda que o "maior dos homens" - mergulhada no contínuo sofrimento implícito à busca da realização dos desejos. Alexandre nada pode oferecer a Diôgenes - no máximo, poderia lhe tirar algo.

$\mathrm{Na}$ perspectiva cínica, a áskesis constitui-se como exercício e cuidado com sua própria natureza, articulando a aceitação de limites com o enfrentamento das dificuldades, "na medida disto, a áskesis cínica é ao mesmo tempo um grito de autêntica franqueza e uma desavergonhada coragem de ser quem se é"33.

A partir do que vimos, pode-se considerar a presença de dois principais elementos cínicos na formulação eudemonológica de Schopenhauer: (1) a busca de "uma vida isenta de dores" e (2) a ênfase na prática de "exercícios" para um modo de vida em "conformidade com sua própria natureza", do qual decorre a importância da "coragem".

Cabe considerar que apesar da Máxima Geral para Sabedoria de Vida, tal como formulada em ASV, apresentar-se por meio da sentença aristotélica de que "O prudente aspira não ao prazer, mas a ausência de dor", a compreensão de seu significado no conjunto da proposta eudemonológica de Schopenhauer segue uma perspectiva cínica/estóica. Já no comentário a este princípio, o filósofo refere-se ao cinismo, considerando que "a partir disso podemos até deduzir a ideia fundamental do cinismo", remetendo em seguida o leitor à sua análise de tais concepções. Embora haja generosas referências a Aristóteles, todo o texto de Aforismos é profundamente marcado pela sabedoria estóica entendida por Schopenhauer como "uma elaboração teórica da prática cínica". De fato, em sua excelente análise sobre a Razão Prática (ou Prudentia) em Schopenhauer, Viesenteiner destaca, com toda a razão, a apropriação que o filósofo faz das máximas aristotélicas a serviço da construção de sua proposta eudemonológica, descontextualizando-as do edifício teórico que é próprio ao estagirita:

[Schopenhauer] apenas instrumentaliza, operacionaliza ou faz uso do texto aristotélico em seus próprios interesses, inclusive deslocando semânticas ou resignificando certos conceitos. Em suma, se o eixo é deslocado da sabedoria estoica às máximas aristotélicas nos Aforismos, isso significa que Schopenhauer faz uso não do horizonte da ética aristotélica, pautada na construção da assim denominada excelência moral, mas muito mais instrumentaliza suas máximas, empregando-as como lente de aumento para que ele exprima seus próprios pensamentos, a sua própria sabedoria de vida ${ }^{34}$.

Todavia, não me parece que seja o caso de afirmar que há propriamente um "deslocamento da sabedoria estóica para as máximas aristotélicas" em Aforismos para Sabedoria de Vida. Talvez seja melhor afirmar que há uma instrumentalização das máximas de Aristóteles à luz de uma compreensão

\footnotetext{
${ }^{33}$ PINHEIRO, Ascese cínica e a oposição Nómos e Phýsis, p. 12, grifos meus.

34 VIESENTEINER, J. L. 'Prudentia'e o uso prático da Razão em Schopenhauer. In: Revista Voluntas, no prelo. Refiro-me ao texto de Jorge Luiz Viesenteiner apresentado na $6^{a}$ edição do Congresso Para saber mais Schopenhauer, realizado entre 29 de maio a 1 de junho de 2012, na Unicentro, em Guarapuava/PR. O autor gentilmente disponibilizou o artigo (no prelo), que está sendo publicado na presente edição da Revista Voluntas.
} 
ainda profundamente estóica da prática de vida - e poderíamos também acrescentar: de significativas raízes cínicas.

O mapeamento destes elementos cínicos, presentes na eudemonologia schopenhaueriana, pode ser interessante para melhor compreender que aqui se trata de uma afirmação consciente da vontade de vida, diante de um diagnóstico trágico acerca da existência. Para a conquista da Sabedoria de Vida, é essencial a busca de "uma vida isenta de dores", por meio da "coragem" e da prática de "exercícios" que viabilizem uma vida em "conformidade com sua própria natureza". Tem-se um convite para aprender a lidar com aquilo que somos - o que só se torna possível a partir da existência em nós de algum "espaço de manobra" (Spielraum), ou seja, de uma liberdade de ser o que se é, enfim, a "liberdade que nos resta" para a prática de vida.

Por fim, retomando a famosa metáfora de Schopenhauer ${ }^{35}$ sobre a natureza humana, pode-se dizer que o "homem forte e cego" (a vontade), que carrega sobre seus ombros o "velho aleijado" (o intelecto), realmente não enxerga nada, mas isso não significa que seja surdo. Conhecendo o caráter do cego, se o velho for prudente, saberá dizer aquilo que terá melhores condições de influenciar esse homem a uma vida menos infeliz. Em suma, eis o papel do intelecto: sugestionar o caráter diferenciadamente, estimulando-o ao exercício constante em prol de uma vida melhor. A Sabedoria de Vida é o desafio de encontrar a melhor maneira de ser si mesmo, enfrentando corajosamente o "mal de viver".

\section{Referências}

CHEVITARESE, L. A Ética em Schopenhauer: que "liberdade nos resta" para a prática de vida? Departamento de Filosofia. PUC-Rio, 2005.

. “Schopenhauer e o Estoicismo". In: Revista Etic@, UFSC, vol.11, n.2 (2012). Disponível em http://periodicos.ufsc.br/index.php/ethic/.

GOUlET-CAZÉ, M.O. L'Ascese Cynique. Um Commentaire de Diogène Laerce VI 70-71. Paris: Vrin, 1986.

LAÊRTIUS, D. Vidas e Doutrinas dos filósofos ilustres. Trad. Mario da Gama. Brasília: UNB, 2008.

NIEHUES-PRÖBSTING, H. “A recepção moderna do cinismo. Diógenes e o Iluminismo." In: BRANHAM, R. B. e GOULET-CAZÉ, M.O. Os Cínicos. O movimento cínico na Antiguidade e seu legado. SP: Loyola, 2007.

1988.

. Der Kynismus des Diogenes uns der Begriff des Zynismus, Frankfurt,

\footnotetext{
${ }^{35}$ Ver Suplemento intitulado “Do primado da vontade”. SCHOPENHAUER, MVR II, XIX, pp. 906-907.
} 
PINHEIRO, M. R.: “Ascese cínica e a oposição Nómos e Phýsis”. O que nos faz pensar? PUC-Rio. v. 30, p. 239-252, 2011.

SCHOPENHAUER, A. Die Welt als Wille und Vorstellung. Sämmtliche Werke. Textkritisch bearbeitet und herausgegeben von Wolfgang Frhr. von Löhneysen. Frankfurt am Main: Suhrkamp, 1986.

. Le Monde comme Volonté et comme Représentation. Trad. A. Burdeau (nouv. éd. rév. et corr. par R. Roos). Paris: Press Universitaires de France, $13^{\text {a }}$ éd., 1992.

. O Mundo como Vontade e como Representação. Trad. Jair Barbosa. SP:

UNESP, 2005.

2012. . Sobre a Ética (Parte de P/P). Trad. Flamarion C. Ramos. São Paulo: Hedra, . Aforismos para a sabedoria de vida. Trad. Jair Barboza. São Paulo: Martins

Fontes, 2002.

Paulo: Iluminuras, 2003.

. Fragmentos para História da Filosofia. Trad. Maria Lúcia Cacciola. São

VIESENTEINER, J. L. "Prudentia” e o uso prático da Razão em Schopenhauer". In: Revista Voluntas, no prelo (o referido texto está sendo publicado na presente edição da Revista Voluntas). 